\title{
Epidemiology and risk factors for invasive candidiasis
}

This article was published in the following Dove Press journal:

Therapeutics and Clinical Risk Management

13 February 2014

Number of times this article has been viewed

\author{
Nur Yapar \\ Department of Infectious Diseases \\ and Clinical Microbiology, Faculty \\ of Medicine, Dokuz Eylül University, \\ Izmir, Turkey
}

\begin{abstract}
The number of immunosuppressive patients has increased significantly in recent years. These patients are at risk for opportunistic infections, especially fungal infections. Candidiasis is one of the most frequent fungal infections determined in these immunosuppressive patients and its epidemiology has changed over the last two decades. Recently, new antifungal agents and new therapy strategies such as antifungal prophylaxis, secondary prophylaxis, and preemptive therapy have come into use. These changes resulted in the alteration of Candida species causing invasive infections. The incidence of Candida albicans was decreased in many countries, especially among patients with immunosuppressive disorders, while the incidence of species other than $C$. albicans was increased. In this review, incidence, risk factors, and species distribution of invasive candidiasis are discussed.
\end{abstract}

Keywords: candidemia, invasive candidiasis, incidence, species distribution, risk factors

\section{Introduction}

As a result of presently used treatments for malignant diseases and HIV/AIDS, and the advances in intensive care unit (ICU) interventions and organ transplantation, many diseases no longer pose a threat to humans and life expectancy is prolonged. However, this has also caused an increase in various opportunistic infections, and most of all, fungal infections. With an increase in the number of individuals sensitive to invasive fungal infections, both molds and yeasts have begun to be reported more frequently as pathogens. When all at-risk groups are considered as a whole, it is seen that the leading pathogen is Candida species. ${ }^{1}$ In the USA, it is among the top five pathogens causing nosocomial blood stream infections (BSIs) and Candida species cause $8 \%$ to $10 \%$ of nosocomial BSIs. ${ }^{1-4}$ Population-based surveillance studies report the yearly incidence of Candida infections as eight per 100,000 population. ${ }^{1}$

The scope of candidiasis covers a wide range of diseases from more superficial and milder clinical manifestations such as esophageal or oropharyngeal candidiasis to serious infections including BSIs and disseminated candidiasis, whereas the description of invasive candidiasis (IC) encompasses severe diseases such as candidemia, endocarditis, disseminated infections, central nervous system infections, endophthalmitis, and osteomyelitis. ${ }^{2}$ Underlying malignancies, immunosuppressive diseases, hematopoietic stem cell or solid organ transplantation, the use of wide-spectrum antibiotics or corticosteroids, invasive interventions, aggressive chemotherapy, parenteral alimentation, and internal prosthetic devices increase the risk of candidiasis. ${ }^{2}$ In spite of the advances achieved in the diagnosis and treatment of candidiasis, the infection still causes high mortality rates. ${ }^{2,5}$
Correspondence: Nur Yapar

Department of Infectious Diseases and Clinical Microbiology, Faculty of Medicine, Dokuz Eylül University, Mithatpasa Street, 35340 Inciralti İzmir,Turkey Email nur.yapar@deu.edu.tr; nuryapar@gmail.com cc) (i) (5) 2014 Yapar. This work is published by Dove Medical Press Limited, and licensed under Creative Commons Attribution - Non Commercial (unported, v3.0) BY LC License. The full terms of the License are available at http://creativecommons.org/licenses/by-nc/3.0/. Non-commercial uses of the work are permitted without any further permisson frese limited, provided the work is properly attributed. Permissions beyond the scope of the License are administered by Dove Medical Press Limited. Information on how to request permission may be found at: http://www.dovepress.com/permissions.php 
Currently, there are more than 150 known species of Candida. However only 15 of these species are isolated from patients as infectious agents. These are Candida albicans, Candida glabrata, Candida tropicalis, Candida parapsilosis, Candida krusei, Candida guilliermondii, Candida lusitaniae, Candida dubliniensis, Candida pelliculosa, Candida kefyr, Candida lipolytica, Candida famata, Candida inconspicua, Candida rugosa, and Candida norvegensis. Although the isolation frequencies may vary, in the last 20-30 years, it has been determined that in $95 \%$ of infections, the pathogens involved are C. albicans, C. glabrata, C. parapsilosis, C. tropicalis, and C. krusei. ${ }^{1,2,6,7}$ Among these species, C. albicans is still the most common pathogen in spite of its dwindling share. In humans, it generally colonizes some regions including skin, oropharynx, lower respiratory tract, gastrointestinal tract, and genitourinary system. ${ }^{1,2}$ The isolation rates of species other than C. albicans vary according to the features (age, underlying diseases, hospitalization ward, etc) of patient population. To illustrate, C. parapsilosis causes $30 \%$ of the candidemia cases among newborns whereas the rate is $10 \%-15 \%$ among adults. C. glabrata is a more common infectious agent among older and neoplastic patients. C. tropicalis, on the other hand, is more commonly seen among leukemia patients and neutropenic patients. Since $C$. parapsilosis colonizes the skin, it is a common pathogen in catheter-related infections and may cause outbreaks. C. krusei, on the other hand, is more common among hematopoietic stem cell recipients or neutropenic leukemia patients receiving fluconazole prophylaxis. ${ }^{1,2}$

The present article reviews the incidence of IC, the most common infectious pathogens and the risk factors for candidiasis. For this purpose, a literature search was performed in last 15 years via PubMed using keywords candidemia, invasive candidiasis, epidemiology, surveillance, incidence, species distribution, and risk factors. National or multinational surveillance studies and multicenter studies written in English were included. The studies were evaluated according to the following regions of the world: North America, Latin America, Europe, Asia-Pacific, Middle East, and Africa. In case of lack of surveillance studies or multicenter researches, large series conducted in a single center were included.

\section{The incidence of IC}

A brief review of the epidemiologic studies related to invasive fungal infections shows that articles where national surveillance data are examined and multicenter studies mostly originate from North America. Although there are some multicenter studies in the literature that originate from
European countries and some other parts of the world, most of these articles generally include data from single centers. The number of national surveillance studies and multinational researches has shown an increase in the last 10 years. Along with studies conducted in single centers, epidemiologic studies analyzing certain patient groups (ICU patients, patients with hematologic malignancies, solid organ transplant recipients, newborns, geriatric patients, etc) also result in overly diverse epidemiological data.

According to the data provided by the Centers for Diseases Control and Prevention (CDC) and the National Healthcare Safety Network, Candida species are ranked fifth among hospital-acquired pathogens and fourth among BSI pathogens. ${ }^{1-4} \mathrm{IC}$ seems to be more of a nosocomial infection when its hospital incidence and health-care-associated risk factors such as the involvement of invasive interventions and long-term antibiotic use are considered. However, the rate of community-acquired cases is not to be underestimated. According to the results of the SENTRY Antimicrobial Surveillance Program, 1,354 infection episodes related to Candida species were detected between 2008 and 2009 and $36.5 \%$ of these were community-acquired. ${ }^{8}$ Communityacquired candidemia was found to be significantly higher in North America (63.5\%) than in Europe (22.4\%). ${ }^{8}$

\section{Data from population-based studies}

It was reported that the incidence rates of IC have increased both in Europe and the USA from the 1970s to the early 1990s and were stabilized after the 1990 s..$^{1,2,9}$ The first reports about the population-based incidence of candidiasis are the CDC data collected between 1992 and $1993 .{ }^{9}$ According to those data, the yearly incidence of IC was reported as 7.28/100,000 population. In a study by Zilberberg et al, despite regional differences, candidemia incidence was found to be 3.65 per 100,000 population in 2000 and 5.56 per 100,000 population in 2005 and the increase throughout the years was found to be significant. ${ }^{10}$ The authors documented a $50 \%$ increase in hospitalization with candidemia from January 2000 to December 2005. ${ }^{10}$ The regional differences in incidence are more prominent in studies planned by the $\mathrm{CDC}$, which were conducted in Atlanta, GA, USA and Baltimore, MD, USA. During 1992-1993, candidemia incidence was found as 8.7/100,000 in Atlanta, whereas an incidence of 24/100,000 was determined in Baltimore between 1998 and 2000. ${ }^{11,12}$ According to a surveillance study conducted in the same regions between 2008 and 2011, the incidence was calculated as 13.3 and 26.2 per 100,000 population for Atlanta and Baltimore, respectively. ${ }^{11,12}$ The yearly IC incidence reported 
on the USA National Center for Health Statistics is eight per 100,000 population. ${ }^{13}$

Except for Denmark, IC incidence in Europe is lower than in the USA. According to the national surveillance studies conducted between 2004-2009 and 2010-2011, the mean incidences in 2004-2009 and 2010-2011 periods were found as 8.6 (minimum: 7.9, maximum: 9.8) and 9.4 (minimum: 8.82, maximum: 10.05) cases per 100,000 inhabitants, respectively. ${ }^{14,15}$ Even lower rates were determined in Finland and Sweden. Poikonen et al reported a yearly mean incidence of 2.86 cases per 100,000 population in Finland between 2004 and 2007. ${ }^{16}$ As for Sweden, a yearly incidence of 4.2 cases/100,000 population was determined between 2005 and $2006 .^{17}$

A population-based surveillance study conducted in Australia between 2001 and 2004 reported a yearly candidemia incidence of 1.81 cases per 100,000 population. ${ }^{18}$ Chen et al reported that the incidence rate was highest among infants and adults aged 65 years and older (24.8 and $13.7 / 100,000$ population, respectively). ${ }^{18}$ Studies on children also support these findings. IC incidence is much higher among infants than in adults and children from other age groups. In England and Wales, the overall yearly candidemia incidence was found to be $1.52 / 100,000$ population and it was reported that among infants aged under 1 year old, the rate was $11 / 100,000 .^{19}$

\section{Data from hospital-based studies}

A review of surveillance studies reveals that, along with population-based studies, there are many multicenter studies involving hospitalized patients. Since such studies calculate incidence rates based on the number of patients admitted to hospitals or on hospitalization days, it may be more appropriate to compare the results of those studies between each other. As in community-based surveillance studies, regional differences also appear in studies investigating infection frequency among hospitalized patients. According to the statistics of the National Hospital Discharge Survey, yearly IC incidence in the US between 1996 and 2003 was 19-24 infections per 10,000 hospital discharges. ${ }^{1}$

Two multicenter epidemiological studies covering the years 2008-2009 and 2009-2010 were conducted in Spain. Tertiary hospitals with high bed capacity were included into both. According to the results of these studies, candidemia incidence in 2008-2009 and 2009-2010 was 1.09 cases/1,000 admissions and 0.92 cases/1,000 admissions, respectively. ${ }^{20,21}$ In Italy, an increase in the candidemia rate was reported between 1999 and 2009 according to the results of multicenter studies. The candidemia rate was found as 1.19 cases/1,000 admissions in 2009, while this rate was 0.38/1,000 admissions in the 1997-1999 period. ${ }^{22}$

Although a smaller number of studies on IC have been conducted in Latin America than in North America, some multicenter studies provide information about IC epidemiology. A study including seven countries and conducted between 2008 and 2010 reported a candidemia incidence of 1.18/1,000 admissions. In the study, the country with the highest incidence rate was Argentina (1.95 cases per 1,000 admissions), followed by Venezuela ( 1.72 cases per 1,000 admissions), Brazil (1.38 cases per 1,000 admissions), Honduras ( 0.90 cases per 1,000 admissions), Ecuador ( 0.90 cases per 1,000 admissions), and Chile (0.33 cases per 1,000 admissions). ${ }^{23}$ The first multicenter and laboratory-based surveillance study in Brazil, which was conducted in 2003-2004, reported a high incidence of candidemia (2.49 cases per 1,000 admissions). ${ }^{24}$ The reason behind this higher candidemia incidence in Brazil is not fully understood. However, this may result from some problems affecting developing countries such as limited resources, insufficient infection control methods due to undereducated health care personnel, and less aggressive empirical antifungal treatment and prophylaxis. ${ }^{24,25}$ In the study performed by Nucci et al in the 2008-2010 period, the incidence of IC in Brazil decreased to 1.38 cases per 1,000 admissions. ${ }^{23}$ The review of the literature did not reveal any hospital-based studies on the incidence of IC in Asia-Pacific countries and Africa.

\section{Data from special patient groups}

The review showed that, in studies about the epidemiology of Candida infections, the frequency and characteristics of these infections have been separately investigated for ICU patients and specific patient groups such as those with underlying hematological or solid organ malignancies. In ICUs, which are hospital areas at high risk for Candida infections, the incidence of candidemia increases in parallel with the increase in general population. Data from the SENTRY Antimicrobial Surveillance Program, which was an international surveillance research program including several countries from Europe, North America, and Latin America, showed that 44.5\% of candidemias were ICU-acquired in the 2008-2009 period. ${ }^{26}$ Various studies have shown that the rate of candidemia in the ICU to be $0.5-32$ cases per 1,000 admissions. ${ }^{27-32}$ In the Extended Prevalence of Infection in Intensive Care (EPIC II) study conducted in ICUs throughout the world in 2007, the prevalence of Candida bloodstream infections was reported as 
Table I Incidence rates of invasive candidiasis

\begin{tabular}{|c|c|c|c|c|c|}
\hline Country & $\begin{array}{l}\text { Study } \\
\text { period }\end{array}$ & $\begin{array}{l}\text { Rate/I,000 } \\
\text { admissions }\end{array}$ & $\begin{array}{l}\text { Rate/ } 10,000 \\
\text { patient-days }\end{array}$ & $\begin{array}{l}\text { Rate/ I00,000 } \\
\text { population }\end{array}$ & Reference \\
\hline \multicolumn{6}{|l|}{ International studies } \\
\hline Europe ECMM & $1997-1999$ & & & & 35 \\
\hline - France & & 0.20 & & & \\
\hline \multicolumn{6}{|l|}{ - Germany } \\
\hline - Italy & & 0.38 & 3.1 & & \\
\hline - Sweden & & 0.32 & 4.4 & & \\
\hline - UK & & & 3.0 & & \\
\hline Latin America & $2008-2010$ & 1.18 & 2.3 & & 23 \\
\hline - Argentina & & 1.95 & 2.4 & & \\
\hline - Brazil & & 1.38 & 2.6 & & \\
\hline - Chile & & 0.33 & 0.9 & & \\
\hline - Colombia & & 1.96 & 1.6 & & \\
\hline - Ecuador & & 0.90 & 1.6 & & \\
\hline - Honduras & & 0.90 & 2.5 & & \\
\hline - Venezuela & & 1.72 & - & & \\
\hline \multicolumn{6}{|c|}{ Nationwide and multicenter studies } \\
\hline United States (CDC) & $1992-1993$ & & & 7.28 & 1 \\
\hline \multirow[t]{2}{*}{ United States } & 2000 & & & 3.65 & 10 \\
\hline & 2005 & & & 5.56 & 10 \\
\hline United States & $2008-2011$ & & & & 11,12 \\
\hline - Atlanta & & & & 13.3 & \\
\hline - Baltimore & & & & 26.2 & \\
\hline Canada & $1992-1996$ & 0.45 & & & 36 \\
\hline \multirow[t]{2}{*}{ Finland } & $1995-1999$ & & & 1.9 & 37 \\
\hline & 2004-2007 & & & 2.86 & 16 \\
\hline Sweden & $2005-2006$ & & & 4.2 & 17 \\
\hline Switzerland (FUNGINOS) & $|99|-2000$ & & 0.49 & & 38 \\
\hline \multirow[t]{2}{*}{ Denmark } & 2004-2009 & & & 8.6 & 14 \\
\hline & $2010-2011$ & & & 9.4 & 15 \\
\hline \multirow[t]{3}{*}{ Spain } & $2002-2003$ & 0.53 & 0.73 & 4.3 & 39 \\
\hline & 2008-2009 & 1.09 & & & 20 \\
\hline & $2009-2010$ & 0.92 & & & 21 \\
\hline Italy & 2009 & 1.19 & 1.20 & & 22 \\
\hline UK & $1997-1999$ & 1.87 & 0.3 & & 40 \\
\hline Norway & $|99|-2003$ & & & 2.4 & 41 \\
\hline Brazil & $2003-2004$ & 2.49 & 3.7 & & 24 \\
\hline Australia & $200 I-2004$ & 0.21 & & 1.81 & 18 \\
\hline Japan & $2008-2012$ & & $0.004-0.008$ & & 42 \\
\hline Thailand & $2005-2007$ & & 1.2 & & 43 \\
\hline \multicolumn{6}{|c|}{ Studies performed for specific patient populations } \\
\hline US (hematological malignancy) & $200 \mathrm{I}-2007$ & & 1.9 & & 44 \\
\hline EPIC II study* (ICU) & 2007 & 6.87 & & & 33 \\
\hline France (ICU) & $200 \mathrm{I}-2002$ & 6.7 & & & 45 \\
\hline Italy (ICU) & $1983-2002$ & 2.6 & 3.3 & & 27 \\
\hline Italy (ICU-AURORA) & 2007-2008 & 16.5 & & & 46 \\
\hline People's Republic of China (ICU) & $2009-2011$ & 32 & & & 32 \\
\hline Germany (ICU) & $2006-2011$ & & 0.7 & & 47 \\
\hline Turkey (ICU) & 2004-2008 & 12.3 & 23.1 & & 48 \\
\hline Germany (pediatric) & $1998-2008$ & 0.47 & & & 49 \\
\hline UK & 2000-2009 & & & & 19 \\
\hline - $<15$ years & & & & 1.52 & \\
\hline - <I year & & & & 11 & \\
\hline
\end{tabular}

Note: *Extended prevalence of infection in ICU.

Abbreviations: CDC, Centers for Disease Control and Prevention; ECMM, European Confederation of Medical Mycology; FUNGINOS, fungal infection network of Switzerland; ICU, intensive care unit. 
Table 2 Species distribution of Candida species isolated in global studies (\%)

\begin{tabular}{|c|c|c|c|c|c|c|c|}
\hline Year & Description & Reference & $\begin{array}{l}\text { Candida } \\
\text { albicans }\end{array}$ & $\begin{array}{l}\text { Candida } \\
\text { tropicalis }\end{array}$ & $\begin{array}{l}\text { Candida } \\
\text { parapsilosis }\end{array}$ & $\begin{array}{l}\text { Candida } \\
\text { glabrata }\end{array}$ & $\begin{array}{l}\text { Candida } \\
\text { krusei }\end{array}$ \\
\hline \multirow[t]{5}{*}{ 1997-2007 } & Laboratory-based & 53 & 65.3 & 7.2 & 6.0 & 11.3 & 2.4 \\
\hline & ARTEMIS & & & & & & \\
\hline & - 1997-2000 & & 70.9 & 5.4 & 4.8 & 10.2 & 2.2 \\
\hline & - 200I-2004 & & 62.9 & 7.5 & 6.9 & 11.5 & 2.5 \\
\hline & - 2005-2007 & & 65 & 8.0 & 5.6 & 11.7 & 2.5 \\
\hline \multirow[t]{2}{*}{2003} & Laboratory-based & 54 & 48.7 & 10.9 & 17.3 & 17.2 & 1.9 \\
\hline & SENTRY & & & & & & \\
\hline \multirow[t]{2}{*}{ 2008-2009 } & Laboratory-based & 57 & 48.4 & 10.6 & 17.1 & 18.2 & 2.0 \\
\hline & SENTRY & & & & & & \\
\hline $2007-2011$ & Hospital-based, pediatric & 55 & 44 & & 22 & II & 3 \\
\hline
\end{tabular}

6.87 per 1,000 ICU patients. ${ }^{33}$ It has been determined that $36 \%$ of invasive fungal infections are caused by yeast in patients with hematological malignancies and Candida species are the cause in $91 \%$ of these yeast infections..$^{34}$ In patients with hematological or solid organ malignancies and neutropenia, C. glabrata and C. tropicalis are more commonly seen than the other Candida species. On the other hand, C. krusei is the most commonly encountered Candida species in patients who have undergone hematopoietic stem cell transplantation and in patients receiving fluconazole prophylaxis. ${ }^{2}$

The results of the studies about IC incidence that could be accessed in the literature review are summarized in Table 1. ${ }^{1,10-12,14-24,35-49}$

As seen from the results of the studies mentioned above, IC exhibits different regional incidence rates throughout the world and epidemiological features of IC may change depending on geographic region. The reasons for those differences are not completely known, but probably are related to a combination of factors including differences in patient demographics (such as age, sex, etc) and comorbidities. Incidence of IC is higher among infants younger than 1 year old and adults older than 70 years old. ${ }^{35,50}$ Patient groups that have high risk for development of IC are patients hospitalized in ICUs, patients with solid or hematological malignancy, or patients undergoing surgery, especially major abdominal or thoracic operations. ${ }^{2,9}$ Other reasons for the changing incidence rates in different series and countries may also be related to bed size of hospitals included in the studies; differences in medical practices such as the use of longterm vascular catheters, antibacterial and antifungal agents; differences in resources available for diagnosis and medical care; and insufficiency or difficulties in implementation of infection control precautions. ${ }^{9,25,30}$

\section{Species distribution}

Although there are over 150 Candida species in nature, only 15 of them are human pathogens. In the last 20 years, a change has been observed in the rates of Candida species isolated from patients with candidiasis. The incidence of C. albicans has decreased, while that of the non-albicans Candida has increased. Although this change has multiple causes, the foremost of these are fluconazole use and the increasing popularity of venous catheters. ${ }^{1,2,9,50-52} \mathrm{~A}$ review of national, regional, and worldwide studies may show that, throughout the years, the incidence of $C$. albicans has declined from $70 \%$ to $50 \% .{ }^{51}$ It has been reported that, in North America and many European countries, the gradually decreasing C. albicans infections have been replaced by

Table 3 Species distribution of Candida species isolated from North America (\%)

\begin{tabular}{llllllll}
\hline Year & Description & Reference & $\begin{array}{l}\text { Candida } \\
\text { albicans }\end{array}$ & $\begin{array}{l}\text { Candida } \\
\text { tropicalis }\end{array}$ & $\begin{array}{l}\text { Candida } \\
\text { parapsilosis }\end{array}$ & $\begin{array}{l}\text { Candida } \\
\text { glabrata }\end{array}$ & $\begin{array}{l}\text { Candida } \\
\text { krusei }\end{array}$ \\
\hline $1992-1996$ & $\begin{array}{l}\text { Canada (three centers) } \\
\text { Laboratory-based }\end{array}$ & 36 & 64 & 11 & 11 & - & 11 \\
$1997-2007$ & 53 & 48.9 & 7.3 & 13.6 & 21.1 & 3.1 \\
$2004-2008$ & $\begin{array}{l}\text { ARTEMIS (USA) } \\
\text { Hospital-based }\end{array}$ & 56 & 42.1 & 8.7 & 15.9 & 26.7 & 3.4 \\
$2008-2009$ & $\begin{array}{l}\text { PATH-ALIANCE (USA) } \\
\text { Laboratory-based }\end{array}$ & 57 & 43.4 & 10.5 & 17.1 & 23.5 & 1.9 \\
$2008-2011$ & $\begin{array}{l}\text { SENTRY (USA) } \\
\text { Population-based (USA) }\end{array}$ & 11,12 & 38 & 10 & 17 & 29 & - \\
\hline
\end{tabular}


Table 4 Species distribution of Candida species isolated from Latin America (\%)

\begin{tabular}{|c|c|c|c|c|c|c|c|}
\hline Year & Description & Reference & $\begin{array}{l}\text { Candida } \\
\text { albicans }\end{array}$ & $\begin{array}{l}\text { Candida } \\
\text { tropicalis }\end{array}$ & $\begin{array}{l}\text { Candida } \\
\text { parapsilosis }\end{array}$ & $\begin{array}{l}\text { Candida } \\
\text { glabrata }\end{array}$ & $\begin{array}{l}\text { Candida } \\
\text { krusei }\end{array}$ \\
\hline 1997-2007 & ARTEMIS Latin America & 53 & 51.8 & 13.2 & 10.3 & 7.4 & 1.4 \\
\hline $2008-2009$ & SENTRY Latin America & 57 & 43.6 & 17.0 & 25.6 & 5.2 & 1.4 \\
\hline $2007-2008$ & Argentina Laboratory-based & 59 & 38.4 & 15.4 & 26.0 & 4.3 & 0.4 \\
\hline \multirow[t]{7}{*}{$2008-2010$} & Laboratory-based & 23 & & & & & \\
\hline & - Argentina & & 42.5 & 16.8 & 23.9 & 6.2 & 1.8 \\
\hline & - Brazil & & 40.5 & 13.2 & 25.8 & 10.0 & 4.7 \\
\hline & - Chile & & 42.1 & 10.5 & 28.9 & 7.9 & 7.9 \\
\hline & - Colombia & & 36.7 & 17.4 & 38.5 & 4.6 & - \\
\hline & - Ecuador & & 52.2 & 10.9 & 30.4 & 4.3 & - \\
\hline & - Honduras* & & 27.4 & 26.7 & |4.| & 3.7 & 3.0 \\
\hline
\end{tabular}

C. glabrata infections, while the incidence of $C$. parapsilosis or C. tropicalis infections has increased in other regions. The distribution of Candida species causing IC is shown in Table 2. ${ }^{53-55,57}$

In North America, the isolation ratio of C. albicans was $64 \%$ in Canada and $48.9 \%$ in USA in the 1990 s. ${ }^{36,53}$ This ratio was decreased to $38 \%$ in the $2008-2011$ period and there was a gradual increase in the ratio of $C$. tropicalis, $C$. parapsilosis, and C. glabrata (Table 3). ${ }^{11,12,36,53,56,57}$

A close examination of the distribution of Candida species causing IC in Latin America countries shows that C. albicans is the most commonly encountered species. However, unlike North America, C. glabrata infections are not so common in Latin America. Instead, the second most common infectious agent is $C$. parapsilosis in many Latin America countries. It has been reported that $C$. parapsilosis, an infectious agent that mostly affects neonates or patients with venous catheters hospitalized in ICUs, is seen among all age groups in Latin America. ${ }^{25}$ Although not clearly identified, it is assumed that this result is associated with insufficient catheter maintenance and infection control methods. A multinational, laboratory-based study from the same region showed that $C$. guilliermondii infections were also common, especially in Honduras. This may be explained by the outbreaks that occurred in the region when the study was conducted (Table 4)..$^{23,53,58,59}$

Table 5 Species distribution of Candida species isolated from Europe (\%)

\begin{tabular}{|c|c|c|c|c|c|c|c|}
\hline Year & Location & Reference & $\begin{array}{l}\text { Candida } \\
\text { albicans }\end{array}$ & $\begin{array}{l}\text { Candida } \\
\text { tropicalis }\end{array}$ & $\begin{array}{l}\text { Candida } \\
\text { parapsilosis }\end{array}$ & $\begin{array}{l}\text { Candida } \\
\text { glabrata }\end{array}$ & $\begin{array}{l}\text { Candida } \\
\text { krusei }\end{array}$ \\
\hline 1997-1999 & ECMM Europe & 35 & 56.4 & 7.2 & 13.3 & 13.6 & 1.9 \\
\hline 1997-2007 & ARTEMIS Europe & 53 & 67.9 & 4.9 & 4.2 & 11.3 & 3.4 \\
\hline 2008-2009 & SENTRY Europe & 57 & 55.2 & 7.3 & 13.7 & 15.7 & 2.5 \\
\hline 2002 & Belgium & 58 & 55 & 2.8 & 13 & 22 & 2.3 \\
\hline 2004-2009 & Denmark & 14 & 57.1 & 4.8 & 3.7 & 21.1 & 4.1 \\
\hline 20I0-20II & Denmark & 15 & 52.1 & 4.1 & 4.2 & 28 & 4.8 \\
\hline $1995-1999$ & Finland & 37 & 70 & 3 & 5 & 9 & 8 \\
\hline 2004-2007 & Finland & 16 & 67 & 2 & 5 & 19 & 3 \\
\hline 2004-2005 & Germany & 60 & 58.5 & 7.5 & 8 & 19.1 & 1.4 \\
\hline 2006-20II & Germany (ICU) & 47 & 66 & & & & \\
\hline 2007-2008 & Italy (AURORA-ICU) & 46 & 40.2 & 9.8 & 36.9 & 9.8 & - \\
\hline 2009 & Italy & 22 & 50.4 & 8.2 & 14.8 & 20.3 & \\
\hline $199 \mid-2003$ & Norway & 41 & 69.8 & 6.7 & 5.8 & 13.2 & 1.6 \\
\hline $2008-2009$ & Spain & 20 & 49.0 & 10.7 & 20.7 & 13.6 & 2.1 \\
\hline $2009-2010$ & Spain (FUNGEMYCA) & 21 & 44.7 & 8.2 & 26.6 & 11.5 & 2.0 \\
\hline $2009-2010$ & Spain FUNGEMYCA (pediatric) & 61 & 36.5 & 5.9 & 46.8 & 3.9 & 1.0 \\
\hline $2005-2006$ & Sweden & 17 & 60.8 & 2.0 & 8.9 & 20.1 & 1.2 \\
\hline $199 \mid-2000$ & Switzerland (FUNGINOS) & 38 & 68 & 9 & I & 15 & 2 \\
\hline 1997-1999 & UK and Wales & 40 & 64.7 & 4.4 & 7.4 & 16.2 & 2.9 \\
\hline 2008 & UK & 62 & 53.7 & 3.2 & 10.7 & 25.8 & 1.0 \\
\hline 2008-2009 & Turkey & 63 & 45.8 & 24.1 & 14.5 & 4.8 & - \\
\hline
\end{tabular}

Abbreviations: ECMM, European Confederation of Medical Mycology; FUNGINOS, fungal infection network of Switzerland; ICU, intensive care unit. 
Table 6 Species distribution of Candida species isolated from Asia-Pacific region (\%)

\begin{tabular}{|c|c|c|c|c|c|c|c|}
\hline Year & Description & Reference & $\begin{array}{l}\text { Candida } \\
\text { albicans }\end{array}$ & $\begin{array}{l}\text { Candida } \\
\text { tropicalis }\end{array}$ & $\begin{array}{l}\text { Candida } \\
\text { parapsilosis }\end{array}$ & $\begin{array}{l}\text { Candida } \\
\text { glabrata }\end{array}$ & $\begin{array}{l}\text { Candida } \\
\text { krusei }\end{array}$ \\
\hline 1997-2007 & ARTEMIS Asia-Pacific & 53 & 64.4 & 11.7 & 7.4 & 12.6 & 1.2 \\
\hline 2008-2009 & SENTRY Asia-Pacific & 57 & 56.9 & 11.7 & 13.7 & 13.7 & 2.0 \\
\hline $200 I-2004$ & Australia & 18 & 47.3 & 5.1 & 19.9 & 15.4 & 4.3 \\
\hline $200 I-2004$ & Australia (ICU) & 29 & 62 & 5.6 & 7.8 & 17.9 & 3.9 \\
\hline 2000-2009 & $\begin{array}{l}\text { People's Republic } \\
\text { of China (single center) }\end{array}$ & 64 & 35.9 & 21.8 & 7.7 & 12.9 & - \\
\hline 2009-20II & $\begin{array}{l}\text { People's Republic } \\
\text { of China (ICU) }\end{array}$ & 32 & 41.8 & 17.6 & 23.8 & 12.3 & - \\
\hline $2005-2007$ & Thailand & 43 & 35.6 & 27.1 & 15.7 & 16.3 & - \\
\hline
\end{tabular}

Abbreviation: ICU, intensive care unit.

In European countries, species distribution of Candida isolates differs from one country to another. For example, in Finland, the incidence of $C$. albicans as a percentage of total Candida was found to be $70 \%$ and $67 \%$ in the $1995-1999$ and 2004-2007 periods, respectively ${ }^{16,37}$ C. glabrata is the secondmost common species. Similarly, in Sweden and Switzerland, the ratio of C. albicans is above $60 \%$ and followed by C. glabrata. ${ }^{17,38}$ However, in Spain the ratio of C. albicans is below $50 \%$ and the most common non-albicans Candida species is C. parapsilosis. ${ }^{20,21,61}$ Likewise, in another Mediterranean country, Italy, $C$. albicans is responsible for almost $50 \%$ of the IC cases and followed by C. parapsilosis. ${ }^{22,46} \mathrm{In}$ Germany, Denmark, and the UK, C. albicans is isolated from more than $50 \%$ of cases and the second-most common isolate is C. glabrata (Table 5). ${ }^{14-17,20-22,35,37,38,40,46,47,53,57,59-63}$

Although a small number of multicenter and comprehensive studies have been conducted in Asia-Pacific countries, Australia, Africa, and the Middle East, those that could be accessed point out a decrease in non-albicans Candida species (Tables 6 and 7). 18,29,32,43,53,57,64,65

Candida infections are commonly seen among cancer patients, and of these infections, $49 \%$ are caused by C. albicans, while $11 \%, 10 \%, 9 \%$, and $11 \%$ are caused by C. tropicalis, C. glabrata, C. krusei, and C. parapsilosis, respectively. ${ }^{66}$ The same study also reported that, in patients with hematological malignancies, $C$. albicans declined to $36 \%$, while $C$. tropicalis was seen among $14 \%$ of these patients and C. parapsilosis, C. glabrata, and C. krusei share a rate of $13 \%{ }^{66}$

From the perspective of species distribution of isolates causing IC, geographic variations are also seen as in the incidence rate. The cause of these variations is multifactorial, but the most important factors affecting species distribution are differences in the antifungal treatment practices and frequency of using invasive procedures such as indwelling catheters. ${ }^{2}$ In addition, demographical features of patients and chronic underlying diseases are also important for causative agents. For example, while $C$. parapsilosis is isolated from candidemia in young infants, C. glabrata is more common among older patients. ${ }^{1,2}$

In the studies investigating risk factors for candidemia caused by non-albicans Candida species, the duration of central venous catheter use; prophylactic or therapeutic fluconazole use; and proportion of days of fluconazole exposure, gastrointestinal surgery, older age, intravenous drug use, glucocorticoid therapy, and candiduria were found as significant risk factors, especially for C. glabrata and C. krusei. Younger age, prior exposure to echinocandin antifungals, and insufficiency in infection control practices have been associated with C. parapsilosis infections. ${ }^{29,30,67}$

\section{Risk factors for IC}

Risk factors for IC may be assigned into two groups: hostrelated factors and health-care-associated factors including catheter use, total parenteral nutrition, surgical interventions, and the use of antimicrobial drugs. The leading host-related factors are immunosuppressive diseases, neutropenia, age, and a deteriorating clinical condition due to underlying diseases. ${ }^{2,28,29,31}$ The most common health-care-associated risks are long hospital or ICU stay. ${ }^{1}$ Risk factors associated with long ICU stay include invasive interventions and

Table 7 Species distribution of Candida species isolated from Africa and Middle-East region (\%)

\begin{tabular}{|c|c|c|c|c|c|c|c|}
\hline Year & Description & Reference & $\begin{array}{l}\text { Candida } \\
\text { albicans }\end{array}$ & $\begin{array}{l}\text { Candida } \\
\text { tropicalis }\end{array}$ & $\begin{array}{l}\text { Candida } \\
\text { parapsilosis }\end{array}$ & $\begin{array}{l}\text { Candida } \\
\text { glabrata }\end{array}$ & $\begin{array}{l}\text { Candida } \\
\text { krusei }\end{array}$ \\
\hline 1997-2007 & ARTEMIS (Africa-Middle East) & 53 & 67.1 & 6.6 & 6.0 & 8.8 & 1.6 \\
\hline $1990-2007$ & South Africa (single center) & 65 & 45.9 & 3.3 & 25 & 19.8 & 3.3 \\
\hline
\end{tabular}


colonization. Candida colonization is a risk factor, the importance of which has been realized in recent years. According to various studies, this risk factor for IC development is more related to the presence or absence of colonization than the number of regions colonized. ${ }^{68,69}$ However, the detection of colonization in any part of the body is only a risk factor, not a disease, and treatment should not be started. Regardless, the lack of Candida colonization is a strong indicator in favor of excluding IC diagnosis. ${ }^{68,69}$

There are many studies in the literature that include patients hospitalized in ICUs and aim at determining risk factors for candidemia. A study by Leroy et al, which included 180 ICUs in France, reported the following as risks factors for candidemia due to IC: surgical interventions, mechanical ventilation, previously received antibiotic treatment, neutropenia, and solid tumor and hematological malignancies. ${ }^{31}$

In another study investigating significant risk factors in patients with candidemia, total length of hospital stay, the presence of central venous catheters, previous candidemia attacks, parenteral nutrition, and chronic renal insufficiency were identified as significant risk factors through multivariate logistic regression analyses. ${ }^{70}$

The increase in the number of IC cases caused by nonalbicans Candida species has required a closer inspection of risk factors. A study conducted between 2001 and 2005 in Greece identified glucocorticoid use, presence of central venous catheters, and candiduria as independent risk factors for infections due to non-albicans species. ${ }^{30}$ A similar study

Table 8 Risk factors for invasive candidiasis for adults and children

Hematological or solid malignancies

Neutropenia

Renal failure

Severe acute pancreatitis

Organ transplantation

Long hospitalization period in the intensive care unit

High APACHE II (Acute Physiology and Chronic Health Evaluation) score Hemodialysis

Usage of antibiotics with broad spectrum

Usage of antifungal agents

Presence of central venous catheters

Mechanical ventilation

Total parenteral nutrition

Usage of immunosuppressive agents

Colonization with Candida species

Surgical procedures

For neonates and children, in addition to adults

Prematurity

Low birth weight

Low APGAR (American Pediatric Gross Assessment) score

Congenital malformations conducted in the USA between 1995 and 2005 reported that the duration of fluconazole treatment and of central venous catheterization are significant risk factors for the development of candidemia. ${ }^{67}$ A national prospective study from Australia, which was conducted during 2001-2005 and included 50 ICUs, identified the following as significant risk factors for nonalbicans Candida infections: previous systematic antifungal therapy, gastrointestinal surgery, old age, and intravenous drug use. ${ }^{28}$ Risk factors for IC are summarized in Table 8.

\section{Conclusion}

Unfortunately, studies about the epidemiology of IC do not present easily comparable figures. This results mostly from the different characteristics of the study methods and study groups. Studies conducted in a certain region are more beneficial in determining the changes in infection frequency. While national and population-based surveillance data collected in the USA and European countries provide a more reliable comparison, most of the studies conducted in other regions are based on single hospitals. Although population-based studies give an idea about the incidence of IC in the general population, those conducted in hospitals base their rates on the number of hospital admissions or hospital stay. Moreover, it is very likely that IC incidence rates might have been determined to be higher than normal in surveillance studies based on hospitals, since the majority of patients included in these studies have underlying chronic diseases and invasive interventions are common procedures in hospitals. Thus, it is difficult to properly interpret the results about the epidemiology of IC in spite of the numerous studies on the subject.

Despite all of the complicated data, it can be assumed in light of a rough evaluation of the epidemiologic studies that the incidence of IC has increased throughout the world. This increase is most pronounced among specific patient groups, especially those hospitalized in ICUs. A similar increase is also noted in population-based studies. Although there are a small number of national and multinational studies on infection frequency, it can be asserted that the incidence of IC varies from one country to another. To illustrate, studies from the USA report higher incidence rates compared to those from the European countries. As for European countries, IC incidence is generally low except for Denmark, where the rate is close to that of the USA.

In addition to the increase in infection frequency, another intriguing development is the change in the distribution of the pathogens causing IC. Until recently, C. albicans was responsible for the majority of infections. However, hospital- and community-acquired infections by non-albicans species have 
become more common today. In some parts of the world, this increase is more pronounced in specific patient groups such as hematologic malignancy patients. Global studies report a decrease from $65 \%$ to $44 \%$ in cases of IC caused by C. albicans between the late 1990s and 2010. However, an increase in the incidence of $C$. tropicalis and $C$. parapsilosis has been observed (Table 2). The greatest clinical risk posed by nonalbicans Candida species, which have become more common, is the changes in their sensitivity to frequently used antifungal agents. Thus, the incidence of these species is closely monitored throughout the world. Similarly to infection frequency, the results of studies related to this subject vary between geographical regions. For instance, C. glabrata incidence is high in the USA, whereas the most commonly observed species in studies from Latin America and Asia-Pacific countries are C. tropicalis and C. parapsilosis (Tables 3 and 4). As for Europe, as a whole, $C$. glabrata and $C$. parapsilosis are among the most common pathogens. The incidence of $C$. parapsilosis is also significantly high in Mediterranean countries.

Despite all epidemiological data, IC still has high crude and attributable mortality. For better management of Candida infections, it is crucial to obtain sufficient epidemiological data. To this end, both infection frequency and species distribution must be regularly monitored through well-planned studies.

\section{Disclosure}

The author reports no conflicts of interest in this work.

\section{References}

1. Pfaller MA, Diekema DJ. Epidemiology of invasive candidiasis: a persistent problem. Clin Microbiol Rev. 2007;20(1):133-163.

2. Pappas PG. Invasive candidiasis. Infect Dis Clin North Am. 2006;20(3): 485-506.

3. Sievert DM, Ricks P, Edwards JR, et al; National Healthcare Safety Network (NHSN) Team and Participating NHSN Facilities. Antimicrobialresistant pathogens associated with healthcare-associated infections: summary of data reported to the National Healthcare Safety Network at the Centers for Disease Control and Prevention, 2009-2010. Infect Control Hosp Epidemiol. 2013;34(1):1-14.

4. Wisplinghoff H, Bischoff T, Tallent SM, Seifert H, Wenzel RP, Edmond MB. Nosocomial bloodstream infections in US hospitals: Analysis of 24,179 cases from a prospective nationwide surveillance study. Clin Infect Dis. 2004;39(3):309-317.

5. Gudlaugsson O, Gillespie S, Lee K, et al. Attributable mortality of nosocomial candidemia, revisited. Clin Infect Dis. 2003;37(9):1172-1177.

6. Diekema D, Arbefeville S, Boyken L, Kroeger J, Pfaller M. The changing epidemiology of healthcare-associated candidemia over three decades. Diagn Microbiol Infect Dis. 2012;73(1):45-48.

7. Lewis RE. Overview of the changing epidemiology of candidemia. Curr Med Res Opin. 2009;25(7):1732-1740.

8. Pfaller MA, Moet GJ, Messer SA, Jones RN, Castenheire M. Candida bloodstream infections: Comparison of species distributions and antifungal resistance patterns in community-onset and nosocomial isolates in the SENTRY antimicrobial surveillance program, 2008-2009. Antimicrob Agents Chemother. 2011;55(2):561-566.
9. Lass-Flörl C. The changing face of epidemiology of invasive fungal disease in Europe. Mycoses. 2009;52(3):197-205.

10. Zilderberg MD, Shorr AF, Kollef MH. Secular trends in candidemiarelated hospitalization in the United States, 2000-2005. Infect Control Hosp Epidemiol. 2008;29(10):978-980.

11. Lockhart SR, Iqbal N, Cleveland AA, et al. Species identification and antifungal susceptibility testing of Candida bloodstream isolates from population-based surveillance studies in two US cities from 2008 to 2011. J Clin Microbiol. 2012;50(11):3435-3442.

12. Cleveland AA, Farley MM, Harrison LH, et al. Changes in incidence and antifungal drug resistance in candidemia: Results from populationbased laboratory surveillance in Atlanta and Baltimore, 2008-2011. Clin Infect Dis. 2012;55(10):1352-1361.

13. Invasive Candidiasis Statistics [webpage on the Internet]. Atlanta: Centers for Disease Control and Prevention; 2012. Available from: http:// www.cdc.gov/fungal/candidiasis/invasive/statistics.html. Accessed October 24, 2013.

14. Arendrup MC, Bruun B, Christensen JJ, et al. National surveillance of fungemia in Denmark (2004 to 2009). J Clin Microbiol. 2011;49(1):325-334.

15. Arendrup MC, Dzajic E, Jensen RH, et al. Epidemiological changes with potential implication for antifungal prescription recommendations for fungaemia: data from a nationwide fungaemia surveillance programme. Clin Microbiol Infect. 2013;19(8):E343-E353.

16. Poikonen E, Lyytikäinen O, Anttila VJ, et al. Secular trend in candidemia and the use of fluconazole in Finland, 2004-2007. BMC Infect Dis. 2010;10:312.

17. Ericsson J, Chryssanthou E, Klingspor L, et al. Candiaemia in Sweden: a nationwide prospective observational survey. Clin Microbiol Infect Dis. 2013;19(4):E218-E221.

18. Chen S, Slavin M, Nguyen Q, et al; Australian Candidemia Study. Active surveillance for candidemia, Australia. Emerg Infect Dis. 2006;12(10):1508-1516.

19. Oeser C, Lamagni T, Heath PT, Sharland M, Ladhani S. The epidemiology of neonatal and pediatric candidemia in England and Wales, 2000-2009. Pediatr Infect Dis J. 2013;32(1):23-26.

20. Cisterna R, Ezpeleta G, Tellaria O, et al; Spanish Candidemia Surveillance Group. Nationwide sentinel surveillance of bloodstream Candida infections in 40 tertiary care hospital in Spain. J Clin Microbiol. 2010;48(11):4200-4206.

21. Pemán J, Cantón E, Quindós G, et al; FUNGEMYCA Study Group. Epidemiology, species distribution and in vitro antifungal susceptibility of fungaemia in a Spanish multicentre prospective survey. JAntimicrob Chemother. 2012;67(5):1181-1187.

22. Tortorano AM, Prigitano A, Lazzarini C, et al. A 1-year prospective survey of candidemia in Italy and changing epidemiology over one decade. Infection. 2013;41(3):655-662.

23. Nucci M, Queiroz-Telles F, Alvarado-Matute T, et al; Latin American Invasive Mycosis Network. Epidemiology of candidemia in Latin America: a laboratory-based survey. PLoS One. 2013;8(3):e59373.

24. Colombo AL, Nucci M, Park BJ, et al; Brazilian Network Candidemia Study. Epidemiology of candidemia in Brazil: a nationwide sentinel surveillance of candidemia in eleven medical centers. J Clin Microbiol. 2006;44(8):2816-2823.

25. Nucci M, Queiroz-Telles F, Tobón AM, Restrepo A, Colombo AL. Epidemiology of opportunistic fungal infections in Latin America. Clin Infect Dis. 2010;51(5):561-570.

26. Pfaller MA, Messer SA, Moet GJ, Jones RN, Castanheira M. Candida bloodstream infections: Comparison of species distribution and resistance to echinocandin and azole antifungal agents in Intensive Care Unit (ICU) and non-ICU settings in the SENTRY antimicrobial surveillance program. Int J Antimicrob Agents. 2011;38(1):65-69.

27. Tortorano AM, Caspani L, Rigoni AL, Biraghi E, Sicignano A, Viviani MA. Candidosis in the intensive care unit: a 20 -year survey. J Hosp Infect. 2004;57(1):8-13.

28. Bouza E, Muñoz P. Epidemiology of candidemia in intensive care units. Int J Antimicrob Agents. 2008;32 Supp1 2:S87-S91. 
29. Playford GE, Marriott D, Nguyen Q, et al. Candidemia in nonneutropenic critically ill patients: Risk factors for non-albicans Candida spp. Crit Care Med. 2008;36(7):2034-2039.

30. Dimopoulos G, Ntziora F, Rachiotis G, Armaganidis A, Falagas ME. Candida albicans versus non-albicans intensive care unit-acquired bloodstream infections: differences in risk factors and outcome. Anesth Analg. 2008;106(2):523-529, table of contents.

31. Leroy O, Gangneux JP, Montravers P, et al; AmarCand Study Group. Epidemiology, management, and risk factors for death of invasive Candida infections in critical care: a multicenter, prospective, observational study in France (2005-2006). Crit Care Med. 2009;37(5):1612-1618.

32. Guo F, Yang Y, Kang Y, et al; China-SCAN Team. Invasive candidiasis in intensive care units in China: a multicentre prospective observational study. J Antimicrob Chemother. 2013;68(7):1660-1668.

33. Kett DH, Azoulay E, Echeverria PM, Vincent JL; Extended Prevalence of Infection in ICU Study (EPIC II) Group of Investigators. Candida bloodstream infections in intensive care units: analysis of the extended prevalence of infection in intensive care unit study. Crit Care Med. 2011;39(4):665-670.

34. Pagano L, Caira M, Candoni A, et al. The epidemiology of fungal infections in patients with hematologic malignancies: the SEIFEM-2004 study. Haematologica. 2006;91(8):1068-1075.

35. Tortorano AM, Peman J, Bernhardt H, et al; ECMM Working Group on Candidaemia. Epidemiology of candidaemia in Europe: results of 28-month European Confederation of Medical Mycology (ECMM) hospital-based surveillance study. Eur J Clin Microbiol Infect Dis. 2004;23(4):317-322.

36. Macphail GL, Taylor GD, Buchanan-Chell M, Ross C, Wilson S, KureishiA. Epidemiology, treatment and outcome of candidemia: a five-year review at three Canadian hospitals. Mycoses. 2002;45(5-6):141-145.

37. Poikonen E, Lyytikäinen O, Anttila VJ, Ruutu P. Candidemia in Finland, 1995-1999. Emerg Infect Dis. 2003;9(8):985-990.

38. Marchetti O, Bille J, Fluckiger U, et al; Fungal Infection Network of Switzerland. Epidemiology of candidemia in Swiss tertiary care hospitals: secular trends, 1991-2000. Clin Infect Dis. 2004;38(3):311-320.

39. Almirante B, Rodríguez D, Park BJ, et al; Barcelona Candidemia Project Study Group. Epidemiology and predictors of mortality in cases of Candida bloodstream infection: results from population-based surveillance, barcelona, Spain, from 2002 to 2003. J Clin Microbiol. 2005;43(4):1829-1835.

40. Kibbler CC, Seaton S, Barnes RA, et al. Management and outcome of bloodstream infections due to Candida species in England and Wales. $J$ Hosp Infect. 2003;54(1):18-24.

41. Sandven P, Bevanger L, Digranes A, Haukland HH, Mannsåker T, Gaustad P; Norwegian Yeast Study Group. Candidemia in Norway (1991 to 2003): results from a nationwide study. J Clin Microbiol. 2006;44(6):1977-1981.

42. Nagao M. A multicentre analysis of epidemiology of the nosocomial bloodstream infections in Japanese university hospitals. Clin Microbiol Infect. 2013;19(9):852-858.

43. Tan TY, Tan AL, Tee NWS, Ng LSY, Chee CW. The increased role of non-albicans species in candidaemia: Results from a 3-year surveillance study. Mycoses. 2010;53(6):515-521.

44. Sipsas NV, Lewis RE, Tarrand J, et al. Candidemia in patients with hematologic malignancies in the era of new antifungal agents (2001-2007): stable incidence but changing epidemiology of a still frequently lethal infection. Cancer. 2009;115(20):4745-4752.

45. Bougnoux ME, Kac G, Aegerter P, d'Enfert C, Fagon JY; CandiRea Study Group. Candidemia and candiduria in critically ill patients admitted to intensive care units in France: incidence, molecular diversity, management and outcome. Intensive Care Med. 2008;34(2):292-299.

46. Montagna MT, Caggiano G, Lovero G, et al. Epidemiology of invasive fungal infections in the intensive care unit: Results of a multicenter Italian survey (AURORA Project). Infection. 2013;41(3):645-653.

47. Meyer E, Geffers C, Gastmeier P, Schwab F. No increase in primary nosocomial candidemia in 682 German intensive care units during 2006 to 2011. Euro Surveill. 2013;18(24).
48. Yapar N, Akan M, Avkan-Oguz V, Ergon M, Hancer M, DolucaYucesoy M. Risk factors and the incidence of candidemia in the intensive care unit: A 5-year cross-sectional study. Proceedings of Twentieth European Congress of Clinical Microbiology and Infectious Diseases (ECCMID); April 10-14, 2010; Vienna, Austria: WileyBlackwell; 2010.

49. Tragiannidis A, Fegeler W, Rellensman G, et al. Candidaemia in a European paediatric university hospital: a 10-year observational study. Clin Microbiol Infect. 2012;18(2):E27-E30.

50. Tortorano AM, Kibbler C, Peman J, Bernhardt H, Klingspor L, Grillot R. Candidemia in Europe: epidemiology and resistance. Int J Antimicrob Agents. 2006;27(5):359-366.

51. Richardson M, Lass-Flörl C. Changing epidemiology of systemic fungal infections. Clin Microbiol Infect. 2008;14 Suppl 4:5-24.

52. Rodloff AC, Koch D, Schauman R. Epidemiology and antifungal resistance in invasive candidiasis. Eur J Med Res. 2011;16(4): 187-195.

53. Pfaller MA, Diekema DJ, Gibbs DL, et al; Global Antifungal Surveillance Group. Results from the ARTEMIS DISK global antifungal surveillance study, 1997 to 2007: a 10.5 year analysis of susceptibilities of Candida species to fluconazole and voriconazole as determined by CLSI standardized disk diffusion. J Clin Microbiol. 2010;48(4):1366-1377.

54. Messer SA, Jones RN, Fritsche TR. International surveillance of Candida spp and Aspergillus spp: Report from the SENTRY antimicrobial surveillance program (2003). J Clin Microbiol. 2006;44(5):1782-1787.

55. Steinbach WJ, Roilides E, Berman D, et al; International Pediatric Fungal Network. Results from a prospective, international, epidemiologic study of invasive candidiasis in children and neonates. Pediatr Infect Dis J. 2012;31(12):1252-1257.

56. Pfaller MA, Neofytos D, Diekema D, et al. Epidemiology and outcomes of candiemia in 3648 patients: data from the Prospective Antifungal Therapy (PATH Alliance ${ }^{\circledR}$ ) registry, 2004-2008. Diagn Microbiol Infect Dis. 2012;74(4):323-331.

57. Pfaller MA, Moet GJ, Messer SA, Jones RN, Castanheira M. Geographic variations in species distribution and echinocandin and azole antifungal resistance rates among Candida bloodstream infection isolates: report from the SENTRY antimicrobial surveillance program (2008-2009). J Clin Microbiol. 2011;49(1):396-399.

58. Swinne D, Watelle M, Suetens C, Mertens K, Fonteyne PA, Nolard N. A one-year survey of candidemia in Belgium in 2002. Epidemiol Infect. 2004;132(6):1175-1180.

59. Córdoba S, Vivot W, Bosco-Borgeat ME, et al; Red Nacional De Laboratorios De Micologia. Species distribution and susceptibility profile of yeasts isolated from blood cultures: results of a multicenter active laboratory-based surveillance study in Argentina. Rev Argent Microbiol. 2011;43(3):176-185.

60. Borg-von Zepelin M, Kunz L, Rüchel R, Reichard U, Weig M, Gross U. Epidemiology and antifungal susceptibilities of Candida spp. to six antifungal agents: Results from a surveillance study on fungaemia in Germany from July 2004 to August 2005. J Antimicrob Chemother. 2007;60(2):424-428.

61. Pemán J, Cantón E, Linares-Sicilia MJ, et al. Epidemiology and antifungal susceptibility of bloodstream fungal isolates in pediatric patients: a Spanish multicenter prospective survey. J Clin Microbiol.2011;49(12): 4158-4163.

62. Chalmers C, Gaur S, Chew J, et al. Epidemiology and management of candidaemia- a retrospective multicentre study in five hospitals in the UK. Mycoses. 2011;54(6):e795-e800.

63. Yapar N, Pullukcu H, Avkan-Oguz V, et al. Evaluation of species distribution and risk factors of candidemia: a multicenter case-control study. Med Mycol. 2011;49(1):26-31.

64. Zhang XB, Yu SJ, Yu JX, Gong YL, Feng W, Sun FJ. Retrospective analysis of epidemiology and prognostic factors for candidemia at a hospital in China, 2000-2009. Jpn J Infect Dis. 2012;65(6):510-515.

65. Kreusch A, Karstaedt AS. Candidemia among adults in Soweto, South Africa, 1990-2007. Int J Infect Dis. 2013;17(8):e621-e623. 
66. Viscoli C, Girmenia C, Marinus A, et al. Candidemia in cancer patients: A prospective, multicenter surveillance study by the Invasive Fungal Infection Group (IFIG) of the European Organization for Research and Treatment of Cancer (EORTC). Clin Infect Dis. 1999;28(5): 1071-1079.

67. Chow JK, Golan Y, Ruthazer R, et al. Factors associated with candidemia caused by non-albicans Candida species versus Candida albicans in the intensive care unit. Clin Infect Dis. 2008;46(8):1206-1213.

68. Pittet D, Monod M, Suter P, Frenk E, Auckenthaler R. Candida colonization and subsequent infections in critically ill surgical patients. Ann Surg. 1994;220(6):751-758.
69. Charles PE, Dalle F, Aube H, et al. Candida spp colonization significance in critically ill medical patients: A prospective study. Intensive Care Med. 2005;31(3):393-400.

70. Bassetti M, Trecarichi EM, Righi E, et al. Incidence, risk factors, and predictors of outcome of candidemia. Survey in 2 Italian university hospitals. Diagn Microbiol Infect Dis. 2007;58(3):325-331.

\section{Publish your work in this journal}

Therapeutics and Clinical Risk Management is an international, peerreviewed journal of clinical therapeutics and risk management, focusing on concise rapid reporting of clinical studies in all therapeutic areas, outcomes, safety, and programs for the effective, safe, and sustained use of medicines. This journal is indexed on PubMed Central, CAS,
EMBase, Scopus and the Elsevier Bibliographic databases. The manuscript management system is completely online and includes a very quick and fair peer-review system, which is all easy to use. Visit http://www.dovepress.com/testimonials.php to read real quotes from published authors.

Submit your manuscript here: http://www.dovepress.com/therapeutics-and-clinical-risk-management-journal 